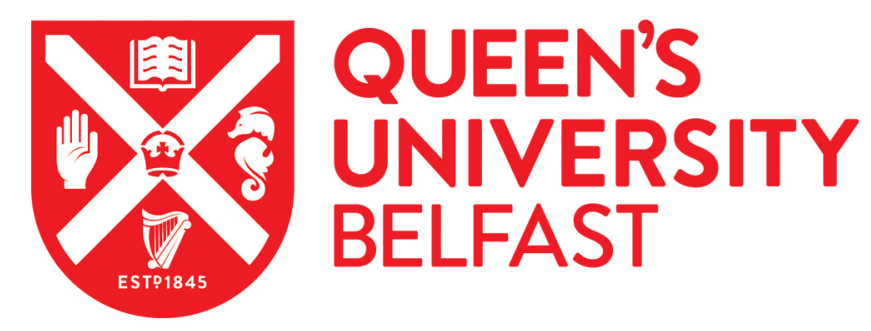

\title{
Can identification as Muslim increase support for reconciliation? The case of the Kurdish conflict in Turkey
}

\author{
Baysu, G., Coskan, C., \& Duman, Y. (2018). Can identification as Muslim increase support for reconciliation? \\ The case of the Kurdish conflict in Turkey. International Journal of Intercultural Relations, 64, 43-53. \\ https://doi.org/10.1016/j.ijintrel.2018.02.002
}

\section{Published in:}

International Journal of Intercultural Relations

\section{Document Version:}

Peer reviewed version

Queen's University Belfast - Research Portal:

Link to publication record in Queen's University Belfast Research Portal

\section{Publisher rights}

Copyright 2018 Elsevier.

This manuscript is distributed under a Creative Commons Attribution-NonCommercial-NoDerivs License

(https://creativecommons.org/licenses/by-nc-nd/4.0/), which permits distribution and reproduction for non-commercial purposes, provided the author and source are cited.

\section{General rights}

Copyright for the publications made accessible via the Queen's University Belfast Research Portal is retained by the author(s) and / or other copyright owners and it is a condition of accessing these publications that users recognise and abide by the legal requirements associated with these rights.

Take down policy

The Research Portal is Queen's institutional repository that provides access to Queen's research output. Every effort has been made to ensure that content in the Research Portal does not infringe any person's rights, or applicable UK laws. If you discover content in the Research Portal that you believe breaches copyright or violates any law, please contact openaccess@qub.ac.uk. 
Can identification as Muslim increase support for reconciliation?

The case of the Kurdish conflict in Turkey

Gülseli Baysu ${ }^{1}$, Canan Coşkan ${ }^{2}$ and Yasin Duman ${ }^{3}$

${ }^{1}$ Corresponding Author: Dr. Gülseli Baysu, Lecturer, School of Psychology, Queen's University Belfast, University Road, BT7 1NN, Belfast, United Kingdom; gulseli.baysu@qub.ac.uk, +44 (0)2890974230

${ }^{2}$ Dr. Canan Coşkan, Guest Lecturer, Institute for Interdisciplinary Research on Conflict and Violence, Bielefeld University, Bielefeld, Germany; canancoskan@gmail.com

${ }^{3}$ Yasin Duman, PhD candidate, Centre for Trust Peace and Social Relations, Coventry University, Coventry, United Kingdom; dumany@uni.coventry.ac.uk

This research did not receive any specific grant from funding agencies in the public, commercial, or not-for-profit sectors.

Word count for the abstract: 230

Word count for the whole text (excluding the tables and figures): 8216 


\begin{abstract}
Ethnic and national identities, as ingroup and superordinate identities, are key predictors for reconciliation, yet less research considers religious identity a superordinate identity. Focusing on the reconciliation of the Kurdish conflict in Turkey, this study aims to test a mediation model in which the relations between ethnic (i.e., Kurdish) and religious identifications (i.e., Muslim) and reconciliation outcomes were mediated by positive intergroup emotions. Moreover, to understand the diffusion of the conflict in a transnational context, this model is tested both in Turkey and Belgium among Muslim Kurdish minorities $(N=141)$. Kurdish minorities' levels of support for reconciliation and the ways they construe reconciliation were analyzed as two outcomes. For the latter, descriptions of reconciliation were first content-coded into seven themes. A latent class analysis of these themes led to two main construals: those endorsing a rights-based versus dialogue-based understanding of reconciliation; which was then used as a binary outcome. Results supported a similar mediation model in Turkey and Belgium. Accordingly, stronger religious identification as Muslim was associated with positive intergroup emotions and in turn more support for reconciliation, whereas stronger ethnic identification as Kurdish had the opposite effect. However, having Muslim identity as a superordinate identity was double-edged for the Kurdish minorities: while high Muslim identifiers were more supportive of reconciliation in general; they were also less likely to endorse a rights-based understanding of reconciliation (versus a dialogue-based reconciliation).
\end{abstract}

Keywords: Reconciliation, the Kurdish conflict, superordinate identity, Muslim, social identity, Turkey 


\section{Can identification as Muslim increase support for reconciliation? The case of the}

\section{Kurdish conflict in Turkey}

In today's world, most countries are composed of different ethnic, racial or religious groups between whom there is often a history of intergroup conflict or a potential for it (Neuberg et al., 2014). Intergroup conflicts not only affect those countries devastated by prolonged (armed) conflict between different groups but also more developed countries, for instance, with forced migration of refugees. Even when the violent conflict is over, the hostility between groups remain, creating a cradle for future conflicts. Reconciliation is thus an important step to achieve long-term peaceful relations following a violent conflict (Bar-Tal \& Bennink, 2004; Kelman, 2004; 2008). Accordingly, we aim to explain the differences in minorities' levels of support for reconciliation as a desired outcome and in the ways they construe what reconciliation means for them (i.e., reconciliation construals). We focus on the case of Kurdish conflict in Turkey and its spill-over in Belgium, as the Kurds constitute the largest minority group in Turkey and the tension between Turkish majority and Kurdish minorities are a long-lasting issue that also affects Kurdish diaspora in Europe (Başer, 2013).

On the explanatory side, deriving from Common Ingroup Identity Model (CIIM, Gaertner \& Davidio, 2000), we investigate the roles of ingroup and superordinate identities in explaining support for and construals of reconciliation. We focus on ethnic Kurdish identity as an in-group identity and the Muslim religious identity as a superordinate identity. To our knowledge, religious identity has rarely been considered as a potential common identity. Several studies in the literature have established ethnic and national identities, as ingroup and superordinate identities, as the main predictors of reconciliation-related outcomes.

Accordingly, the more members of the conflicting groups identify with a common national identity, termed as superordinate identity (Gaertner \& Dovidio, 2000), the more likely they are to forgive the other group (Van Tongeren, Burnette, O'Boyle, Worthington, \& Forsyth, 
2014) or to dissent social distance (Cehajic, Brown, \& Castano, 2008). The opposite holds for identifying with an ethnic ingroup (on intergroup forgiveness, Van Tongeren et al., 2014). Past research considered religious identity mostly as in-group identity and studied religious subdivisions or the groups divided along religious and/or ethnic lines such as in the IsraeliPalestinian conflict (Licata, Klein, Saade, Azzi, \& Branscombe, 2012) or the Northern Ireland conflict (Moeschberger, Dixon, Niens, \& Cairns, 2005; Noor, Brown, \& Prentice, 2008). The Turkish case is unique in the sense that the opposing parties, Turks and Kurds are divided along ethnic lines but not along religious lines. ${ }^{1}$ In this context, we aim to test whether Muslim identity as a common identity would facilitate reconciliation.

Moreover, we propose that the process through which Muslim identity facilitates reconciliation is through enhanced positive intergroup emotions. According to CIIM (Gaertner \& Davidio, 2000), if members of different groups perceive themselves as a more inclusive superordinate group, the former outgroup members would now be seen as ingroup members and thus they would be evaluated more positively, trusted more and liked better (Çelebi, Verkuyten, Köse, \& Maliepaard, 2014; Noor, Brown, Gonzalez, Manzi, \& Lewis, 2008; Noor, Brown, \& Prentice, 2008). Accordingly, this study aims to test a mediation model in which the relations between ethnic (i.e., Kurdish) and religious identifications (i.e., Muslim) and reconciliation outcomes are mediated by positive intergroup emotions (see Figure 1).

Finally, we aim to understand the diffusion of the conflict in a transnational context. The Kurdish conflict is no longer a concern only for Turkey, but, due to the Kurdish Diaspora, has increasingly become a European debate (Başer, 2013). We test whether this mediation model works similarly in Turkey and Belgium among Muslim Kurdish minorities.

To sum up, this study goes beyond previous research (1) by focusing on support for reconciliation and minorities' own understandings of reconciliation as two outcomes (beyond 
the usual focus on other intergroup outcomes such as forgiveness or on the scales of reconciliation with predetermined items), (2) by focusing on religious (Muslim) identity as a superordinate identity and positive emotions as the process through which it affects reconciliation (beyond the usual focus on national identities), and (3) by studying these relations comparatively both in Turkey and in diaspora (beyond the usual focus on the conflict situation only in the country or only in diaspora). In the remainder of the introduction, we will first explain how reconciliation is defined and studied in the literature and in this paper, then focus on the role of identity and intergroup emotions on the explanatory side, and finally we will describe the case of the Kurdish conflict in Turkey and its spill-over in Belgium.

\section{Reconciliation}

Reconciliation is a most desired outcome for stable and lasting peace (Bar-Tal \& Bennink, 2004; Kelman, 2008). However, both theoretically and empirically, it is hard to operationalize the term. Theoretically, its definition entails two seemingly-separate foci. The commonly-understood definition is that it is a psychological change in the motivations, beliefs, attitudes and emotions of the majority of society members (Bar-Tal \& Bennink, 2004). Accordingly, reconciliation is generally considered as a psychological process of mutual acceptance, communication and respect (Kanazayire, Licata, Mélotte, Dusingizemungu, \& Azzi, 2014; Noor, Brown, \& Prentice, 2008; Staub, 2006). This may also be called as the "socio-emotional route" to reconciliation (Nadler \& Shnabel, 2015). However, it has also been suggested that reconciliation is a structural change that requires political and economic integration. This may also be called as the "instrumental route" to reconciliation (Nadler \& Shnabel, 2015). So ideally for reconciliation, structural acts of political and economic integration should be accompanied by psychological changes that support it (Bar-Tal \& Bennink, 2004). 
Empirically, most research does not directly look at reconciliation; the focus is rather on other intergroup outcomes related to reconciliation: such as intergroup attitudes (Licata et al., 2012), forgiveness and attributions of responsibility (Noor, Brown, \& Prentice, 2008), and distance (Cehajic et al., 2008). A few researchers adopted a measurement scale approach to reconciliation. However, the content of such scales differs. For instance, reconciliation has been defined as trust, collaboration with outgroup members and the capacity to control oneself in the presence of the offenders in the Rwandan conflict (Kanazayire et al., 2014; Mukashema \& Mullet, 2010) or as awareness of the need to talk to and interact with the other community in the Northern Ireland conflict (Noor, Brown, Gonzalez et al., 2008) and in the Kurdish conflict (Uluğ \& Cohrs, 2017a). Despite the differences in the scale contents, all of these studies seem to define reconciliation as a psychological change.

There is also a growing line of research with a bottom-up approach to different understandings of the nature of the conflict in which people are involved. Although they do not directly focus on reconciliation, conflict frames are important as they hint at people's subjective evaluation of the past or ongoing conflicts such as attributions of responsibility and sense of victimization (Bar-Tal, 2007). Conflict frames are associated with outgroup (dis)trust (Çelebi et al., 2014) and attitudes towards reconciliation (Bar-Tal, 2013). In the Kurdish conflict, Çelik and Blum (2007) find three conflict frames depending on how the parties involved in the conflict are defined: (1) a conflict between the Turkish state and the Kurdistan Workers' Party (PKK) (the terrorism frame), (2) a conflict between the Turkish state and the residents of Southeast Turkey (minority rights frame), and (3) a conflict between Turks and Kurds (ethnic tensions frame) (see also, Bilali, 2014; Çelebi et al., 2014). Uluğ and Cohrs (2016) focused not only on the parties involved but also on the processes of conflict and on the suggested solutions: In addition to terrorism and minority rights frames, they found an economic inequality frame (suggesting economic development as the solution for the conflict) 
and independence frame (suggesting independent Kurdistan as the solution to the conflict resolution). Minority rights and independence frames were mostly endorsed by Kurdish minorities (Uluğ \& Cohrs, 2016), and both are related to the structural aspects of reconciliation. However, this line of research did not specifically focus on how minorities construe reconciliation, instead of conflict.

In this study, we focus on two reconciliation-related outcomes. First, we ask our participants to what extent they support reconciliation as a desired outcome, regardless of how reconciliation is construed. Moreover, we believe an empirically-driven, bottom-up approach is required to grasp how people construe what reconciliation means to them (similar to studies of conflict construals). To this end, we ask Kurdish participants what reconciliation means to them and how it can be achieved. We first analyze these descriptions via content-coding to derive at common themes. To use this variable as a quantitative outcome in the mediation model, we then do a latent class analysis to see whether our participants holding similar understandings of reconciliation can be grouped along these themes. We tentatively expect at least two main construals that tap into psychological (e.g., mutual acceptance and communication) and structural aspects of reconciliation (e.g., minority rights).

\section{Common Identification as Muslim}

Reconciliation requires a process of identity change (Kelman, 2004; 2008), so that the negation of the other is no longer a central element of one's identity and the development of common identity reinforces reconciliation. According to CIIM in psychology (Gaertner \& Dovidio, 2000), a common identity inclusive of the conflicting parties might enhance positive emotions such as trust and in turn may facilitate reconciliation, whereas strong identification with the conflicting parties might have the opposite effects. Several field and laboratory studies have shown that naturally occurring or induced identification with a common identity increases positive emotions such as trust and empathy (Çelebi et al., 2014; Noor, Brown, 
Gonzales et al., 2008; Noor, Brown, \& Prentice, 2008), intergroup forgiveness (Cehajic et al., 2008; Noor, Brown, Gonzales et al., 2008; Noor, Brown, \& Prentice, 2008; Wohl \& Branscombe, 2008) and reduces attributions of responsibility to the outgroup for harm-doing (Licata et al., 2012), whereas ingroup identification has the opposite effects.

In this line of research, national identity is commonly regarded as the common identity that cross-cuts ethnic and/or religious boundaries between conflicting parties and that leads to positive intergroup outcomes. National identity does not always produce positive intergroup outcomes, however, it depends on the content of national identity (Pehrson, Brown, \& Zagefka, 2009). It has been shown that if national identity is defined as exclusive of immigrants - i.e., an ethnic representation of national identity — it will exacerbate prejudice (Pehrson, Vignoles, \& Brown, 2009).

In the present context, Turks and Kurds have their ethnic group identities, Turk and Kurd respectively; they also share a common religious identity, that is, being Muslim and also a common national identity, being from Turkey (Türkiyeli) or having citizenship of Turkey. Çelebi and her colleagues (2014) looked at ethnic and national identifications in the Kurdish conflict and reported that among Kurds higher national identification as Turkish was related to higher trust for Turks whereas stronger ethnic identification as Kurdish was related to lower trust. Others, however, argued that Kurds in Turkey and abroad conceive Turkish Citizenship as negative and assimilatory (Eliassi, 2016; Kaya, 2016).

We thus propose that religious identity can be a unifying category in the Kurdish conflict. During the peace process, Muslim fellowship was proposed as a common ground upon which the peace process could be built and accepted by the vast majority of the society, by the political leaders of both the governing party (Justice and Development Party, AKP) and the Kurdish minorities in Turkey (Dă̆, 2014; Uluğ \& Cohrs, 2017b; Yeğen, 2015). However, one can question whether the content of Muslim identity is civic or inclusive 
enough (Verkuyten, 2007). Research shows the widespread prejudice against Muslims (e.g., Awan \& Zempi, 2016; Hutchison \& Rosenthal, 2011; Wirtz, van der Pligt, \& Doosje, 2016) and how Muslims and Muslim identity are problematized in Europe (Blackwood, Hopkins, \& Reicher, 2013). Moreover, religious identification is generally associated with prejudice towards other groups (Scheepers, Gijsberts, \& Hello, 2002), and religion associated with conflicts (Neuberg et al., 2014). However, Kunst and Thomsen (2015) show that religion can also create a common in-group. Specifically, they found that Christians were less biased towards the Muslim outgroup when they were reminded that both religions belong to Abrahamic religions. Taking this line of research further, it would be theoretically interesting to see to what extent having stronger Muslim identification among Kurdish minorities would facilitate reconciliation, in a context where Muslim identity is endorsed by the majority of the society and in a socio-political climate where Muslim fellowship was put forth as the basis of reconciliation.

\section{The Role of Intergroup Emotions}

We investigate the role of intergroup emotions as the main mediator between religious and ethnic identifications and reconciliation outcomes. According to CIIM (Gaertner \& Dovidio, 2000), the primary process through which identification with a superordinate category leads to positive intergroup outcomes is through increasing attractiveness and liking of the other group. Group identifications are not only related to perceptions of the conflict (Bilali, 2014; Licata et al., 2002) but also have an emotional meaning (Çelebi et al., 2014). Common identity "interventions generate positive intergroup emotions, and it is these emotions that drive better intergroup relations" (Mackie, Smith \& Ray, 2008, p. 1875). Accordingly, positive intergroup emotions mediated the relationship between common ingroup identity and competitive victimhood as another intergroup outcome (Andrighetto, Mari, Volpato, \& Behluli, 2012). Also, according to reconciliation researchers, reconciliation of 
conflicts requires a change of emotions such as building trust between the parties (Bar-Tal \& Bennink, 2004; Kelman, 2004, 2008; Staub, 2006).

Since research generally focuses on positive intergroup emotions such as trust and liking as the driver of better intergroup relations (Andrighetto et al., 2012; Çelebi et al., 2014; Noor, Brown, Gonzales et al., 2008; Noor, Brown, \& Prentice, 2008), we expect that identification as Muslim would be associated with more positive emotions towards the Turkish majority group which turn would predict Kurds' support for reconciliation, while identification as Kurdish would have the opposite effects. As for the relationship between identification as Muslim or Kurdish and minorities' own construals of reconciliation, we do not have any a priori hypotheses as these construals were driven bottom-up from contentcoding (see Figure 1).

\section{The Kurdish conflict in Turkey and its spill-over in Belgium}

This study also aims to understand the diffusion of the conflict beyond the national borders in Turkey to a transnational context. We thus investigate to what extent similar associations hold between Muslim and Kurdish identifications, intergroup emotions and reconciliation outcomes in Turkey and in Belgium. In Turkey, Kurds are the biggest minority group, making up an estimated 15-20\% of the population (KONDA, 2006; Sirkeci, 2005). The tension between the Turkish majority and the Kurdish minority groups can be traced back to the foundation of Turkish Republic in 1923. After the Ottoman Empire, the new Turkish state was founded on the ideals of national unity, with Turkish as the national language and the ethnic Turks as the founders. Hence, the recognition of different minority groups or their cultural rights has been largely neglected in the history of Turkey. Efforts by the Kurds to move towards political representation, freedom from discrimination, and recognition of their identity as an ethnic group, have been marred by oppression (Yıld1z, 2012). The armed conflict between the Kurdistan Workers' Party (PKK) and the state dates back to 1980s. 
Nearly 30.000 people have been killed in this conflict, which mostly took place in southeastern Turkey. During the peace process between 2012-2015, there was some progress towards cease-fire and granting cultural rights. The negotiations between the parties could be dated back earlier to 2008-2009 (ICG, 2004; Yeğen, 2015). However, the peace process was halted and the violent armed conflicts have resumed (Yeğen, 2015). This survey took place during the ceasefire while the peace negotiations were going on.

Also in the European countries where they reside, Kurds maintain their Kurdish identity and use opportunities to mobilize their movement. Both the Kurdish and the Turkish immigrants in Europe engage in "identity-making" processes and sustain identity boundarymaintenance vis-à-vis each other (Başer, 2013). Therefore, the intergroup tension between Turks and Kurds often spreads to European countries where a large group of immigrants from Turkey reside (Başer, 2013; Østergaard-Nielsen, 2001). We focus on Belgium, as an exemplary yet understudied case of Kurdish European diaspora (for Germany and Sweden, see Başer, 2013). In Belgium, immigrants from Turkey are one of the biggest immigrant groups, making up $1.5 \%$ of the population. Unfortunately, there is no official statistics about different ethnic groups who migrated from Turkey to Belgium (but see Casier, 2011). The intergroup tension between Turks and Kurds often shows itself in Belgium through riots and protests (JimmisVideos, 2011; Koutroubas, Vloeberghs, \& Yanasmayan, 2009). For instance, the peace process in Turkey became a matter of political discussion in Belgium (Casier, 2011). While the tension spreads to Belgium, and Kurds and Turks maintain and mobilize on the grounds of their identities, the intergroup boundaries could be still less salient in Belgium where both groups are in the minority position, compared to Turkey where Kurds are the disadvantaged minority while Turks are in the majority position. So, it would be practically and theoretically interesting and novel to investigate across both countries to what extent the 
national Zeitgeist of the Kurdish-Turkish relations in terms of the processes predicting reconciliation is mirrored on the transnational context (Figure 1).

\section{Method}

\section{Respondents}

Respondents were Kurdish minority group members from Turkey ( $n=75,33 \%$ female) and Belgium $(n=66,29 \%$ female). Their age ranged between 17 to 51 years $(M=27.24, S D=$ 6.94), though $86.5 \%$ of respondents were younger than 34. Participants in Belgium were immigrants from Turkey (Mage of immigration $=20.71)$ with half $(51.5 \%)$ stating their reason of immigration as seeking political refuge. Participants in Istanbul were internal immigrants. Both in Turkey and Belgium, they were mostly first-generation immigrants emigrated from south-eastern Turkey (92\% and $88 \%$ respectively). One third of Kurdish participants in Belgium (33\%) and Turkey (35\%) were raised in both Turkish and Kurdish languages, while $6 \%$ of Kurds in Belgium were raised only in Kurdish compared to $21 \%$ of Kurds in Turkey, $\chi^{2}(2)=5.97, p=.051$. A fair amount $(38 \%)$ of Kurds in Belgium was raised also in Flemish and/or French on top of Kurdish and Turkish languages. Overall, most participants (55.3\%) were highly-educated, with Kurds in Turkey (68\%) having significantly more university students/graduates than those in Belgium $(41 \%), \chi^{2}(2)=10.59, p=.001$. Relatedly, there were more students $(66 \%)$ and thus fewer employed (\%17) respondents in the Turkish sample than in the Belgian sample (33\% and 50\% respectively), and similar levels of unemployed/other in both countries ( $\% 20$ vs. $\% 15$ respectively), $\chi^{2}(2)=18.13, p<.001$. We selectively focused on big cities: Istanbul in Turkey and Leuven, Antwerp, Brussels and Gent in Belgium. Of the eleven million Kurdish minorities in Turkey, an estimated two million live in Istanbul (KONDA, 2006). Hence, Istanbul hosts the largest group of the Kurdish minority in Turkey. Similarly, Turkish and Kurdish immigrants in Belgium are concentrated predominantly in urban areas. 


\section{Procedure}

Participants, all competent in Turkish, received the questionnaire in Turkish. Participants from both countries were reached by convenience sampling method and they completed the questionnaires during one-to-one meetings arranged and conducted by a member of the research team fluent in both Turkish and Kurdish. Confidentiality and anonymity was ensured. Completion of the questionnaire took approximately 45 minutes.

\section{Measures}

Social Identities. We measured ingroup (i.e., Kurdish) and common (i.e., Muslim) identities relevant to Kurdish community with the traditional item used to measure social identities (Postmes, Haslam, \& Jans, 2013) in seven-point Likert scales (ranging from $1=$ Not at All to 7 = Very Strongly): "To what extent do you identify with Kurds" $(M=6.4, S D=1.38)$ and "To what extent do you identify with Muslims" $(M=4.03, S D=2.84)$. The two identities were not correlated $(r=.07, p=.419)$. Given extremely high scores and small variance $(70 \%$ circled the highest possible score, i.e., 7 in a seven-point scale), identification as Kurdish was used as a dummy-coded nominal variable with a mean split: $0=$ Lower Kurdish identification for those scoring 6 or lower, and $1=$ High Kurdish identification for those scoring 7.

Intergroup Emotions. We measured Kurdish participants' positive intergroup emotions toward the outgroup Turks with three questions "How often do you feel trust/admiration/love towards Turks?" (Binder et al. 2009). They were rated in five-point Likert scales $(1=$ Never to $5=$ Very Often, $\alpha=.70 ; M=2.19, S D=.85)$.

Support for Reconciliation. We measured participants' support for reconciliation as a desired outcome with two items: "How desirable do you think is reconciliation?" and "How realistic/likely do you think is reconciliation?” (Hjort \& Frisen, 2006). Answers were recorded on five-point Likert scales $(1=$ Not Likely to $5=$ Very Likely). A composite score was computed from the two items (Spearman-Brown $\rho=.57, p<.001 ; M=2.80, S D=1.04$ ). 
Reconciliation Construals. Construals were measured with an open-ended question: "What does reconciliation mean to you and how can it be achieved?" Answers were first qualitatively explored for themes appearing for more than once, leading to seven themes that appear often in answers. Next, participants' responses were content-coded based on the seven themes; in other words, each response was screened for each of these themes. Finally, a latent class analysis was performed on the emerging themes. Details of this analysis are given under the Results Section.

Control variables. Participants' age, gender and education were tested as control variables; they were dropped from the analyses as they were not significant.

\section{Results}

Comparison of Kurdish Samples in Turkey and Belgium

Means and standard deviations of measures are reported in Table 1. For demographics, Kurds in Turkey and in Belgium had similar gender distributions but they differed in educational levels with fewer Kurds in Belgium having university degree compared to Kurds in Turkey. Additionally, Kurds in Turkey were younger than Kurds in Belgium.

As for the study variables, Kurds' identification with their Kurdish in-group differed with those in Turkey having higher Kurdish identification than those in Belgium, although even in Belgium it was still highly skewed. Their levels of common identification as Muslim were similar across Turkey and Belgium. Kurds in Turkey and Belgium did not differ in terms of their intergroup emotions toward the Turks either. Finally, Kurds in Turkey scored lower on support for reconciliation than Kurds in Belgium.

\section{Reconciliation construals}

First, participants' descriptions of reconciliation were evaluated independently by two raters for possible themes. Seven themes emerged out of 109 responses (see Table 2, first and second columns). Second, three independent raters conducted fully-crossed content-coding 
for these 109 responses in the frame of seven themes. Each response was screened based on whether it included (1) or did not include (0) each of the themes. For instance, a respondent's description of reconciliation as "Reconciliation means mutual respect for opinions of different groups. For reconciliation to take place, these groups need to listen to each other without fighting" was coded 1 under the themes of Dialogue and Respect and as 0 for the other five themes. Another respondent's description of reconciliation as "Creating a context in which Kurds can freely live on their lands and to come to the table with PKK to resolve the conflict" (PKK, the Kurdistan Workers' Party) was coded 1 under the themes of Freedom and Confederation and 0 for the remaining themes. An inter-rater reliability analysis using the Kappa statistic was performed to determine consistency among raters for each theme (see Table 2 , final column). The total average inter-rater was close to perfect $\kappa=.97(p<.001)$ (Hallgren, 2012).

Finally, a series of Latent Class Analyses (LCA) was conducted to group people who hold similar understandings of reconciliation along these seven themes. To this end, seven dummy-coded variables indicating the seven themes were analyzed in LCA. Similar to factor analysis which assumes existence of latent dimensions, LCA assumes existence of latent groups of subjects and that within the same latent group, respondents respond to various items similarly (McCutcheon, 1987). Deciding on the number of clusters in LCA is a function of better fit statistics, interpretability and usefulness (McCutcheon, 1987). Comparing one to three-class solutions, a two-class solution was preferred as it provided better fit statistics and meaningful distinctive classes: Loglikelihood $(\mathrm{LL})(112)=-381.697$, AIC: 793.395 , BIC: 833.765, Entropy: .64 (medium-level certainty). ${ }^{2}$ Odds ratio probability estimates showed that Rights, Freedom, and Confederation were most likely to be classified under rights-based reconciliation and Dialogue, Recognition, Peace, and Emotions were most likely to be classified under dialogue-based reconciliation (see Table 3). Participants' perceptions of 
reconciliations were then coded either as 0 for dialogue-based reconciliation ( $59 \%$ of the participants) or as 1 for rights-based reconciliation ( $41 \%$ of the participants).

\section{Identifications, Emotions and Reconciliation Outcomes}

We tested a mediation model in which intergroup emotions mediated the relations between identifications as Muslim and Kurdish, and support for reconciliation and reconciliation construals as two outcomes (Figure 1) using Mplus Version 7.3 (Muthén \& Muthén, 1998-2012). Whether the Kurdish minorities resided in Turkey or Belgium was also included in the analysis as a predictor and as a moderator. We followed a stepwise approach starting from a saturated model including all possible direct and indirect effects, then removing those that are not significant (Hayes, 2009). Accordingly, the following paths were not significant and hence dropped from the final model: the direct effects of Kurdish and Muslim Identifications on support for reconciliation $\left(\Delta \chi^{2}(1)=.07, p=.809 ; \Delta \chi^{2}(1)=.50, p=\right.$ .478 , respectively) and on reconciliation construals $\left(\Delta \chi^{2}(1)=.37, p=.55 ; \Delta \chi^{2}(1)=.02, p=\right.$ .880 , respectively), and the correlation between support for reconciliation and reconciliation construals $\left(\Delta \chi^{2}(1)=1.15, p=.283\right)$. The final model had a good fit: $\mathrm{RMSEA}=.00$ with $90 \%$ $\mathrm{CI}=[.00-.07] ; \mathrm{CFI}=1.0 .^{3}$

We present the bootstrapped results (10000 replications) of unstandardized regression coefficients and CIs from the final model. Identifications as Muslim and Kurdish predicted support for reconciliation through positive intergroup emotions. First, stronger Muslim identification $(b=.08, S E=.03, p=.003,95 \% \mathrm{BCa} C \mathrm{CI}[.026, .128])$ as well as weaker Kurdish identification $(b=-.40, S E=.14, p=.003,95 \%$ BCa CI [-.655, -.117]) predicted positive intergroup emotions, explaining a total of $11 \%$ of the variance, $R^{2}=.11$. In turn, positive intergroup emotions predicted support for reconciliation $(b=.34, S E=.12, p=.005$, $95 \% \mathrm{BCa}$ CI $[.111, .578]), R^{2}=.13$. The indirect effects of Muslim identification $(b=.03, S E$ $=.01, p=.018 ; 95 \% \mathrm{BCa}$ CI $[.009, .055])$ as well as Kurdish identification $(b=-.14, S E=$ 
$.07, p=.053 ; 95 \% \mathrm{BCa}$ CI [-.307, -.031] on support for reconciliation were significant.

Finally, Kurds' country of residence also predicted support for reconciliation directly:

Compared to Kurds living in Belgium, Kurds living in Turkey had significantly lower support for reconciliation $(b=-.51, S E=.18, p=.004,95 \%$ BCa CI $[-.855,-.151])$.

As for the reconciliation construals outcome, positive intergroup emotions had a significant effect $\left(b=-.38, S E=.17, p=.028,95 \%\right.$ BCa CI [-.692, -.007]) $R^{2}=.10$, showing that positive emotions were associated with endorsing the dialogue-based construal of reconciliation (vs. the rights-based). The indirect effects of Muslim identification on the reconciliation construals was marginally significant $(b=-.03, S E=.02, p=.082 ; 95 \% \mathrm{BCa} \mathrm{CI}$ $[-.071,-.004])$, while the indirect effect of Kurdish identification was not significant, $(b=.15$, $S E=.10, p=.132 ; 95 \% \mathrm{BCa}$ CI $[.012, .403]) .{ }^{4}$ These results show that stronger identification as Muslim was associated with more positive intergroup emotions which in turn was related to stronger endorsement of a dialogue-based construal (vs. rights-based).

Further model tests for interactions with the country of residence yielded nonsignificant results: interactions between country of residence and Kurdish and Muslim identifications on emotions and the two reconciliation outcomes, interaction between country of residence and emotions on two reconciliation outcomes.

\section{Discussion}

Given the importance of reconciliation for stable and long-lasting peace, what fosters reconciliation has been an intriguing question to researchers and policy-makers. Deriving from CIIM (Gaertner \& Davidio, 2000), ethnic and national identifications as ingroup and common identities have emerged as two important predictors for reconciliation, albeit with opposite effects. This study furthered our understanding of the identity-reconciliation relationship in several ways. First, we looked at not only participants' degree of support for reconciliation but also their reconciliation construals, that is, what reconciliation meant for 
them. Second, we looked at the role of identification as Muslim as a common identity rather than the usually-studied national identity. Thirdly, we proposed and found support for the mediating role of intergroup emotions between ethnic and religious identifications and reconciliation outcomes. Finally, results were overall similar across Kurds in Turkey and Belgium, with the exception of a relatively lower support for reconciliation in Turkey. Now we will discuss these four issues.

First, this is the first study, to our knowledge, analyzing minorities' own understandings of reconciliation. We found seven themes that tapped into both psychological and structural aspects of reconciliation. Accordingly, two latent classes were found: those endorsing a more dialogue-based construal of reconciliation (dialogue, recognition, emotions and peace) vs. a more right-based construal (identity rights, freedom and confederative rights). In the literature, both aspects are generally studied in separate lines of research. Scales of reconciliation generally only focus on the dialogue aspect (Kanazayire et al., 2014; Noor, Brown, Gonzales et al., 2008), whereas others working on conflict frames focus only on the structural aspects (Bilali, 2014; Çelik \& Blum, 2007; Uluğ \& Cohrs, 2016). Therefore, our study adds methodologically and theoretically to reconciliation research by showing that minorities conceive reconciliation both in terms of structural and psychological aspects. In the case of the ongoing Kurdish conflict, a demand for minority rights is then not only a reason for the conflict, that is, a conflict frame, (Bilali, 2014; Çelik \& Blum, 2007; Uluğ \& Cohrs, 2016) but also an essential element of reconciliation from the Kurdish minority perspective. Moreover, a sincere dialogue between the conflicting parties is a necessity for achieving longlasting peaceful relations (Çelik, 2014).

Secondly, we looked at whether and how identifications as Muslim and Kurdish were related to reconciliation outcomes. We proposed that when Muslim identity is accepted by the vast majority of the society as in the Kurdish conflict, it should work as a common identity 
cross-cutting ethnic boundaries between Turks and Kurds. Accordingly, identification as Muslim was associated with more positive emotions towards the Turks which in turn predicted support for reconciliation, while identification as Kurdish had the opposite effects. These findings are in line with the expectations of CIIM (Gaertner \& Davidio, 2000) and replicate previous research focusing on ingroup and superordinate identities as predictors of positive intergroup outcomes (Cehajic et al., 2008; Greenaway, Quinn, \& Louis, 2011; Kunst \& Thomsen, 2015; Noor, Brown, \& Prentice, 2008). Moreover, it adds to this line of research showing for the first time that Muslim identity as a common identity can be a facilitator of support for reconciliation.

We also found that identification as Muslim was associated more with a dialoguebased understanding of reconciliation (and thus less with a rights-based understanding of reconciliation) through increasing positive emotions towards the Turkish majority. There is a growing line of research indicating that superordinate identifications, although improving intergroup relations, generally come with a cost for minorities (Dovidio, Gaertner, \& Saguy, 2007), that is, minorities become more accepting of intergroup inequalities (Jaśko \& Kossowska 2013), they become less likely to endorse collective action (Greenaway et al., 2011) and their conflict frames become more similar to that of the majority group in opposition to their own ethnic interests (Bilali, 2014). Similarly, Dixon, Tropp, Durrheim and Tredoux (2010) argued that positive intergroup contacts due to reduced salience of intergroup boundaries may decrease minorities' awareness of their disadvantaged position in the society which would lead to more peaceful but not necessarily more equal relations. Accordingly, identification as Muslim among Kurdish minorities was associated with more support for reconciliation but less with an understanding of reconciliation in terms of minority-rights. This may be a disadvantage for minorities in their struggle for better and more equal political and economic reconciliation. 
Thirdly, our current research replicates the existing findings on the role of positive intergroup emotions for reconciliation but also extends previous research by showing the mediating role of positive emotions between a common religious identity and reconciliation. Previous research showed that positive intergroup emotions such as trust and empathy play an important role as an affective predictor of intergroup forgiveness (Noor, Brown, Gonzalez et al., 2008; Noor, Brown, \& Prentice, 2008). Similarly, positive intergroup emotions such as empathy and trust also decreased competitive victimhood between Serbs and Albanians in the Kosovo case (Andrighetto et al., 2012). Nadler and Liviatan (2006) also showed that empathy when combined with trust led to more positive attitudes towards reconciliation in the Israeli and Palestinian conflict. A change of intergroup emotions for the better seems to be an essential prerequisite of reconciliation (Bar-Tal \& Bennink, 2004; Nadler \& Shnabel, 2015).

Finally, we were interested in the spill-over of the conflict to a transnational context. Results were overall similar across Turkey and Belgium. This is not surprising given that immigrants from Turkey in Europe and in Belgium in particular are strongly attached to their ethnic origin; they stay in closed communities, have strong ethnic ties and follow news and politics from Turkey (Başer, 2013; Phalet, Baysu, \& van Acker, 2015). However, the fact that Kurds in Turkey supported reconciliation less is alarming. Minorities in Europe could be more accustomed to peaceful multicultural ways of living and therefore more supportive of reconciliation. Belgium itself is a multicultural country composed of French, Flemish and German communities (Bousetta \& Swyngedouw, 1999). The difference the national context creates could also be due to the relative lack of salience of the intergroup conflict and the boundaries between Kurds and Turks in Belgium. In Belgium, both Turks and Kurds are a minority group and they do not mingle with each other, stay in their segregated communities and politically organize around their ethnic allegiances (for Germany and the Netherlands, see Østergaard-Nielsen, 2001). The relatively-lower Kurdish identification of Kurds in Belgium 
compared to those in Turkey in this study supports this latter reasoning about the salience of intergroup boundaries. Our study is one of the first comparative studies of the Kurdish conflict both in the country it is situated and in diaspora that it spreads to, and it contributes to the understanding of the understudied intergroup tension between Turks and Kurds in Belgium (for Kurds in European diaspora see van Bruinessen, 1998). Future studies should look into the reasons for the difference in support for reconciliation, such as the salience of intergroup boundaries and endorsing multiculturalism.

One note of caution is that Kurdish respondents in this study were highly-educated and they are not representative of the respective populations. Education level is an important predictor for political mobilization. For the Kurds as a minority group, higher education may increase political mobilization for ingroup rights (for Turkish immigrants in Europe, Fleischmann, Phalet, \& Klein, 2011). Although the findings of this research among educated young people is still important for the resolution of the intergroup conflict in Turkey, future studies should include both educated and uneducated segments of society. Moreover, although selectivity of the samples limits the generalization of the findings, they were similarly selected in both countries in terms of the main demographics, as the compositions of the samples in both countries showed.

An additional limitation of the study is the use of single indicators to assess identities. Although single indicator measures of group identification are commonly used and were proved externally valid (Postmes, Haslam, \& Jans, 2013), more elaborate composite measures of identity would be required to find out whether the findings generalize to different components of group identities. We also found that Kurdish identification was more like a nominal (high or 'total' identification) than a continuous variable. Verkuyten (2007) showed that Muslim identification was a bright boundary among Turkish immigrants in Europe and thus was like a nominal category. It is possible that when a minority identity becomes very 
salient and important, i.e., bright boundary, it is more likely to be a nominal category than a continuous variable. Finally, this study should have ideally included the majority Turkish perspective as well, since the reconciliation requires a change of perspectives of both parties in the conflict (but see Uluğ \& Cohrs, 2017a).

Overall, this research sheds light on the questions what reconciliation means for minorities and why and how ethnic and religious identifications affect reconciliation outcomes. Having Muslim identity as a superordinate identity is double-edged for the Kurdish minorities: while high Muslim identifiers were more supportive of reconciliation in general; they were also less likely to endorse a rights-based understanding of reconciliation (versus a dialogue-based reconciliation). Thus, peace-building efforts should strive not only to foster a common identity and positive emotions among conflicting parties but also to support minority rights in order to achieve peaceful and equal intergroup relations. 


\section{Footnote}

${ }^{1}$ We focus on Muslim religious identification as a common identity. We do not believe the sectarian differences are relevant here as sectarian differences are similarly distributed across Turks and Kurds: The majority of both Turkish and Kurdish Muslims are from the Sunni sect, and only a minority are from the Alevite sect, a more liberal sect of Islam.

${ }^{2}$ One-class model: LL (112) $=-400.844$, AIC: 815.688; BIC: 834.527; three-class model: -371.294, AIC: 788.588, BIC: 850.489, entropy: .97

${ }^{3}$ With categorical outcomes, MPLUS uses WLSMV estimator and Chi-square model fit statistics is not provided.

${ }^{4}$ For the indirect effect of Muslim identification, standardized effect $\beta=-.08, \mathrm{SE}=.05$, $p=.069$; moreover, bootstrapped CIs do not contain zero which provides further support for the presence of a significant relationship 


\section{References}

Andrighetto, L., Mari, S., Volpato, C., \& Behluli, B. (2012). Reducing Competitive Victimhood in Kosovo: The Role of Extended Contact and Common Ingroup Identity. Political Psychology, 33(4), 513-529. DOI: 10.1111/j.1467-9221.2012.00887.x

Awan, I., \& Zempi, I. (2016). The affinity between online and offline anti-Muslim hate crime: dynamics and impacts. Aggression and Violent Behaviour, 27, 1-8. doi:10.1016/j.avb.2016.02.001.

Bar-Tal, D. (2007). Socio-psychological foundations of intractable conflicts. American Behavioral Scientist, 50, 1430-1453. doi:10.1177/0002764207302462.

Bar-Tal, D. (2013). Intractable conflicts: Socio-psychological foundations and dynamics. New York: Cambridge University Press.

Bar-Tal, D., \& Bennink, G. H. (2004). The nature of reconciliation as an outcome and as a process. In Y. Bar-Siman-Tov (Ed.), From conflict resolution to reconciliation (pp. 11-38). Oxford: Oxford University Press.

Başer, B. (2013). The Kurdish Diaspora in Europe: Identity formation and political activism Boğaziçi University-TÜSİAD Foreign Policy Forum Research Report. http://dispolitikaforumu.com/wp-content/uploads/2013/10/Bahar_Baser_RR 01_2013.pdf

Bilali, R. (2014). The downsides of a shared national identification for minority group outcomes in intergroup conflicts in assimilationist societies. British Journal of Social Psychology, 53, 2138. doi:10.1111/bjso.12012.

Binder J., Zagefka, H., Brown, R., Funke, F., Kessler, T., Mummendey, A., Maquil, A., Demoulin, S., \& Leyens, JP. (2009). Does contact reduce prejudice or does prejudice reduce contact? A longitudinal test of the contact hypothesis among majority and minority groups in three European countries. Journal of Personality and Social Psychology, 96(4), 843-856. doi:10.1037/a0013470.

Blackwood, L., Hopkins, N., \& Reicher, S. (2013). I know who I am, but who do they think I am? Muslim perspectives on encounters with airport authorities. Ethnic and Racial Studies, 36(6), 1090-1108. doi:10.1080/01419870.2011.645845. 
Bousetta, H. \& Swyngedouw, M. (1999). La citoyenneté de l'Union Européenne et l'enjeu de Bruxelles. Brussels: Courier Hebdomadaire de CRISP, 1636. doi:10.3917/cris.1636.0001. van Bruinessen, M. (1998). Shifting national and ethnic identities: The Kurds in Turkey and the European Diaspora. Journal of Muslim Minority Affairs, 18(1), 39-52. doi:10.1080/13602009808716392.

Casier, M. (2011). Neglected middle men? Gatekeepers in homeland politics. Case: Flemish nationalists' receptivity to the plight of Turkey's Kurds. Social Identities 17(4), 501-521. doi:10.1080/13504630.2011.587305.

Cehajic, S., Brown, R., \& Castano, E. (2008). Forgive and forget? Antecedents and consequences of intergroup forgiveness in Bosnia and Hercegovina. Political Psychology, 29, 351-368. doi:10.1111/j.1467-9221.2008.00634.x.

Çelebi, E., Verkuyten, M., Köse, T., \& Maliepaard, M. (2014). Out-group trust and conflict understandings: the perspective of Turks and Kurds in Turkey. International Journal of Intercultural Relations, 40, 64-75. doi:10.1016/j.ijintrel.2014.02.002.

Çelik, A. (2014). The need for Reconciliation in the Kurdish issue: Why, how and with whom? [Kürt meselesi'ni dönüştürmede toplumsal mutabakat ihtiyacı: Neden, nasıl, kimle?]. In A. Murat (Ed.), Conflict Resolution and Peace [Çatışma Çözümleri ve Barış] (pp. 131-152). İstanbul: İletişim.

Çelik, A. B., \& Blum, A. (2007). Track II interventions and the Kurdish question in Turkey: An analysis using a theories of change approach. International Journal of Peace Studies, 12(2), 51 - 81. http://www.jstor.org/stable/41852962.

Dağ, R. (2014, June 13). Democratic Islam Congress and the Middle East. Open Democracy. Retrieved from https://www.opendemocracy.net/arab-awakening/rahman-dag/democraticislam-congress-and-middle-east Accessed on 15.06.2016.

Dixon, J., Tropp, L. R., Durrheim, K., \& Tredoux, C. (2010). Let them eat harmony: Prejudice reduction strategies and attitudes of historically disadvantaged groups. Current Directs in Psychological Science, 19(2), 76-80. doi:10.1177/0963721410363366. 
Dovidio, J. F., Gaertner, S. L., \& Saguy, T. (2007). Another view of “we”: Majority and minority group perspectives on a common ingroup identity. European Review of Social Psychology, 18, 296-330. doi: 10.1080/10463280701726132.

Eliassi, B. (2016). Conceiving Citizenship and Statelessness in the Middle East and Sweden: The Experiences of Kurdish migrants in Sweden. In N. Stokes-DuPass \& R. Fruja (Eds.) Citizenship, Belonging, and Nation-States in the Twenty-First Century (pp. 85-110). Palgrave Macmillan.

Fleischmann, F., Phalet, K., \& Klein, O. (2011). Religious identification and politicization in the face of discrimination. Support for political Islam and political action among the Turkish and Moroccan Second Generation in Europe. British Journal of Social Psychology, 50(4), 628648. doi:10.1111/j.2044-8309.2011.02072.x.

Gaertner, S. L., \& Dovidio, J. F. (2000). Reducing intergroup bias: The common in-group identity model. Philadelphia: Psychology Press.

Greenaway, K. H., Quinn, E. A., \& Louis, W. R. (2011). Appealing to common humanity increases forgiveness but reduces collective action among victims of historical atrocities. European Journal of Social Psychology, 41, 569-573. doi:10.1002/ejsp.802.

Hallgren, K. A. (2012). Computing inter-rater reliability for observational data: an overview and tutorial. Tutorials in quantitative methods for psychology, 8(1), 23-24.

Hayes, A. F. (2009). Beyond Baron and Kenny: Statistical mediation analysis in the new millennium. Communication Monographs, 76, 408-420. doi: 10.1080/03637750903310360

Hjort, H. \& Frisen, A. (2006). Ethnic identity and reconciliation: Two main tasks for the young in Bosnia-Herzegovina. Adolescence, 41(161), 141-163.

Hutchison, P., \& Rosenthal, H. E. S. (2011). Prejudice against Muslims: Anxiety as a mediator between intergroup contact and attitudes, perceived group variability and behavioural intentions. Ethnic and Racial Studies, 34(1), 40-61. doi:10.1080/01419871003763312.

ICG (International Crisis Group). (2014). Turkey and the PKK: Saving the Peace Process (Europe Report N²34). Retrieved from http://www.crisisgroup.org/ /media/Files/europe/turkeycyprus/turkey/234-turkey-and-the-pkk-saving-the-peace-process.pdf Accessed on 15.06.2016. 
Jaśko, K., \& Kossowska, M. (2013). The impact of superordinate identification on the justification of intergroup inequalities. European Journal of Social Psychology, 43(4), 255-262. doi:10.1002/ejsp.1946.

JimmisVideos. (2011, November 6). Muslims Riot in Belgium 06/11/2011 -- Turks and Kurds in Savage Street War in Antwerp [Video file]. Retrieved from https://www.youtube.com/watch?v=2iaYb1vFvV0

Kanazayire, C., Licata, L., Mélotte, P., Dusingizemungu, J. P., \& Azzi, A. E. (2014). Does identification with Rwanda increase reconciliation sentiments between genocide survivors and non-victims? The mediating roles of perceived intergroup similarity and self-esteem during commemorations. Journal of Social and Political Psychology, 2(1), 489-504. doi:10.5964/jspp.v2i1.319.

Kaya, A. (2016). Ethno-religious narratives of citizenship in Turkey: Fabricating citizens through national education. Research and Policy on Turkey, 1(2), 119-131.

Kelman, H. C. (2004). Reconciliation as identity change: A social psychological perspective. In BarSiman-Tov, Yaacov (Ed.), From conflict resolution to reconciliation (pp. 111-124). Oxford: Oxford University Press.

Kelman, H. C. (2008). Reconciliation from a social-psychological perspective. In N. Arie, M. Thomas, \& F. Jeffrey D. (Eds.), Social Psychology of Intergroup Reconciliation (pp. 15-32). Oxford and New York: Oxford University Press.

KONDA. (2006). Biz Kimiz? Toplumsal Yapı Araştırması [Who are we? Research on social structure]. http://www.konda.com.tr/tr/raporlar/2006_09_KONDA_Toplumsal_Yapi.pdf Accessed on 15.06.2016.

Koutroubas, T., Vloeberghs, W., \& Yanasmayan, Z. (2009). Political, Religious and Ethnic Radicalisation among Muslims in Belgium. In M. Emerson (Ed.), Ethno-Religious Conflict in Europe: Typologies of Radicalisation in Europe's Muslim Communities (pp.51-80). Brussels: Centre European Policy Studies. 
Kunst, J. R., \& Thomsen, L. (2015). Prodigal Sons: Dual Abrahamic Categorization Mediates the Detrimental Effects of Religious Fundamentalism on Christian-Muslim Relations. The International Journal for the Psychology of Religion, 25(4), 293-306, doi: http://dx.doi.org/10.1080/10508619.2014.937965

Licata, L., Klein, O., Saade, W., Azzi, A. E., \& Branscombe, N. R. (2012). Perceived outgroup (dis)continuity and attribution of responsibility for the Lebanese civil war mediate effects of national and religious subgroup identification on intergroup attitudes. Group Processes and Intergroup Relations, 15(2), 179-192. doi:10.1177/1368430211414445.

Mackie, D. M., Smith, E. R., \& Ray, D. G. (2008). Intergroup emotions and intergroup relations. Social and Personality Psychology Compass, 2(5), doi: 1866-1880, 10.1111/j.17519004.2008.00130.x

McCutcheon, A. C. (1987). Latent class analysis. Beverly Hills: Sage Publications.

Moeschberger, S.L., Dixon, D. N., Niens, U., \& Cairnis, E. (2005). Forgiveness in Northern Ireland: An empirical model for peace in the midst of the "troubles". Peace and Conflict: Journal of Peace Psychology, 41, 115-121. doi:10.1207/s15327949pac1102_5.

Mukashema, I., \& Mullet, E. (2010). Reconciliation sentiment among victims of genocide in Rwanda: Conceptualizations, and relationships with mental health. Social Indicators Research, 99, 2539.

Muthén, B., \& Muthén, L. (1998-2012). Mplus user's guide. Los Angeles, CA: Muthén \& Muthén.

Nadler, A., \& Liviatan, I. (2006). Intergroup reconciliation: Effects of adversary's expressions of empathy, responsibility, and recipients' trust. Personality and Social Psychology Bulletin, 32(4), 459-470. doi:10.1177/0146167205276431.

Nadler, A., \& Shnabel, N. (2015). Intergroup reconciliation: Instrumental and socio-emotional processes and the needs-based model. European Review of Social Psychology, 26(1), 93-125. doi:10.1080/10463283.2015.1106712. 
Neuberg, S. L., Warner, C. M., Mistler, S. A., Berlin, A., Hill, E. D., Johnson, J. D., ... Schober, J. (2014). Religion and intergroup conflict: Findings from the Global Group Relations Project. Psychological Science, 25(1), 198-206. doi: 10.1177/0956797613504303.

Noor, M., Brown, R., Gonzalez, R., Manzi, J., \& Lewis, C. A. (2008). On positive psychological outcomes: What helps groups with a history of conflict to forgive and reconcile with each other? Personality and Social Psychology Bulletin, 34, 819-832. doi:10.1177/0146167208315555.

Noor, M., Brown, R. J. \& Prentice, G. (2008). Precursors and mediators of intergroup reconciliation in Northern Ireland: A new model. British Journal of Social Psychology, 47, 481-495. doi: $10.1348 / 014466607 X 238751$

Østergaard-Nielsen, E. K. (2001). Transnational political practices and the receiving state: Turks and Kurds in Germany and the Netherlands. Global Networks, 1(3), 261-281. doi:10.1111/14710374.00016.

Pehrson, S., Brown, R., \& Zagefka, H. (2009). When does national identification lead to the rejection of immigrants? Cross-sectional and longitudinal evidence for the role of essentialist in-group definitions. British Journal of Social Psychology, 48, 61-76. doi:10.1348/014466608X288827.

Pehrson, S., Vignoles, V. L., \& Brown, R. (2009). National identification and anti-immigrant prejudice: Individual and contextual effects of national definitions. Social Psychology Quarterly, 72, 24-38. doi:10.1177/019027250907200104.

Phalet, K., Baysu, G., \& van Acker, K. (2015). Ethnicity and migration in Europe. In Wright, J. D. (Ed.) International Encyclopedia of the Social and Behavioral Sciences (2nd ed.) (pp. 142147). doi:10.1016/B978-0-08-097086-8.24040-3.

Postmes, T., Haslam, S. A., \& Jans, L. (2013). A single-item measure of social identification: Reliability, validity, and utility. British Journal of Social Psychology, 52(4), 597-617. doi:10.1111/bjso.12006.

Scheepers, P., Gijberts, M., \& Hello, E. (2002). Religiosity and prejudice against ethnic minorities in Europe. Review of Religious Research, 43, 242-265. doi:10.2307/3512331. 
Sirkeci, I. (2005). Exploring the Kurdish Population in the Turkish Context. GENUS, International Journal of Demography, 56(1-2), 149-175. http://works.bepress.com/sirkeci/14/

Staub, E. (2006). Reconciliation after genocide, mass killing, or intractable conflict: Understanding the roots of violence, psychological recovery, and the steps toward a general theory. Political Psychology, 27, 867-894. doi:10.1111/j.1467-9221.2006.00541.x.

Uluğ, Ö. M., \& Cohrs, J. C. (2016). An exploration of lay people's Kurdish conflict frames in Turkey. Peace and Conflict: Journal of Peace Psychology. Advance online publication. doi:10.1037/pac0000165.

Uluğ, Ö. M., \& Cohrs, J. C. (2017a). "If we become friends, maybe I can change my perspective": Intergroup contact, endorsement of conflict narratives and peace-related attitudes in Turkey. Peace and Conflict: Journal of Peace Psychology. http://dx.doi.org/10.1037/pac0000216

Uluğ, Ö. M., \& Cohrs, C. (2017b). "Who will resolve this conflict if the politicians don't?”: Understandings of the Kurdish conflict among members of parliament in Turkey. International Journal of Conflict Management, 28(2), 245-266. Doi: 10.1108/IJCMA-102015-0071

Van Tongeren, D. R., Burnette, J. L., O’Boyle, E., Worthington, E. L., \& Forsyth, D. R. (2014). A meta-analysis of intergroup forgiveness. The Journal of Positive Psychology: Dedicated to furthering research and promoting good practice, 9(1), 81-95. doi:10.1080/17439760.2013.844268

Verkuyten, M. (2007). Religious group identification and inter-religious relations: A study among Turkish-Dutch Muslims. Group Processes and Intergroup Relations, 10, 341-357. doi:10.1177/1368430207078695.

Wirtz, C., van der Pligt, J., \& Doosje, B. (2016). Negative attitudes toward Muslims in the Netherlands: The role of symbolic threat, stereotypes, and moral emotions. Peace and Conflict: Journal of Peace Psychology, 22(1), 75-83. doi: 10.1037/pac0000126.

Wohl, M. J. A., \& Branscombe, N. R. (2008). Remembering historical victimization: Collective guilt for current ingroup transgressions. Journal of Personality and Social Psychology, 94, 9881006. doi:10.1037/0022-3514.94.6.988. 
Yeğen, M. (2015). The Kurdish peace process in Turkey: Genesis, evolution and prospects. In S. Aydın-Düzgit, D. Huber, M. Müftüler-Baç et al., (Eds.), Global Turkey in Europe III: Democracy, Trade, and the Kurdish Question in Turkey-EU Relations, Vol 19 (pp. 157-182). Edizioni Nuova Cultura.

Y1ldı, K. (2012). Turkey’s Kurdish Conflict: Pathways to Progress. Insight Turkey 14(4), 151-174. 
Table 1

Comparison of demographics and study variables across country of residence

\begin{tabular}{llll}
\hline & Turkey & Belgium & Difference test \\
\hline Gender (\% male) & $\% 66.7$ & $\% 71.2$ & $n s$ \\
Education (university) & $\% 68$ & $\% 40.9$ & $p=.005$ \\
Age & $24.04(3.98)$ & $30.88(7.78)$ & $p<.001$ \\
Kurdish Identification & $6.69(0.59)$ & $6.06(1.88)$ & $p=.007$ \\
Muslim Identification & $4.06(2.74)$ & $4.00(3.00)$ & $n s$ \\
Positive emotions & $2.21(0.77)$ & $2.16(0.93)$ & $n s$ \\
Support for Reconciliation & $2.60(0.94)$ & $3.02(1.11)$ & $p=.016$ \\
\hline
\end{tabular}

Notes. For continuous variables, means with standard deviations in parentheses and for categorical variables, percentages are presented. The group difference test for the former is a t-test while for the latter, it is a Chi-square test. 
Table 2

Themes, Contents, and Inter-rater Reliabilities for Reconciliation Construals

\begin{tabular}{|c|c|c|}
\hline Themes & Participants' emphasis on: & $\begin{array}{l}\text { Averaged Inter-rater } \\
\text { reliability }(\kappa)(n=3)\end{array}$ \\
\hline Rights & $\begin{array}{l}\text { Kurdish rights, demands of language, education, } \\
\text { political autonomy and equality }\end{array}$ & $0.93(\mathrm{p}<.001)$ \\
\hline Freedom & $\begin{array}{l}\text { Free choice of people (on the political system, on } \\
\text { the importance of cultural codes etc.) as well as } \\
\text { freedom to Abdullah Öcalan }\end{array}$ & $0.96(\mathrm{p}<.001)$ \\
\hline Confederation & $\begin{array}{l}\text { Kurdish independence, autonomous region, } \\
\text { confederation }\end{array}$ & $0.92(\mathrm{p}<.001)$ \\
\hline Emotions & Empathy, Genuineness, Trust, Happiness. & $1.00(\mathrm{p}<.001)$ \\
\hline Dialogue & $\begin{array}{l}\text { Intergroup communication, talking and } \\
\text { understanding }\end{array}$ & $1.00(\mathrm{p}<.001)$ \\
\hline Recognition & Giving and getting recognition and respect. & $1.00(\mathrm{p}<.001)$ \\
\hline Peace & Constructing peace, ending the war & $0.98(\mathrm{p}<.001)$ \\
\hline
\end{tabular}


Table 3

Latent class membership based on the estimated posterior probability

\begin{tabular}{lll}
\hline Themes & $\begin{array}{c}\text { Rights-based } \\
\text { Reconciliation } \\
(\% 41)\end{array}$ & $\begin{array}{c}\text { Dialogue- } \\
\text { based } \\
\text { Reconciliation } \\
(\% 59)\end{array}$ \\
\hline Rights & $\mathbf{. 7 8 * * *}$ & .12 \\
Freedom & $\mathbf{. 2 5 * *}$ & .00 \\
Confederation & $\mathbf{. 3 2 * *}$ & .00 \\
Dialogue & .18 & $\mathbf{. 6 0 * * *}$ \\
Emotions & .08 & $\mathbf{. 2 7} * *$ \\
Recognition & .16 & $\mathbf{. 2 5} * *$ \\
Peace & .12 & $\mathbf{. 3 3 * * *}$ \\
\hline$* * * \mathrm{p}<.001 * * * \mathrm{p}<01$ & &
\end{tabular}




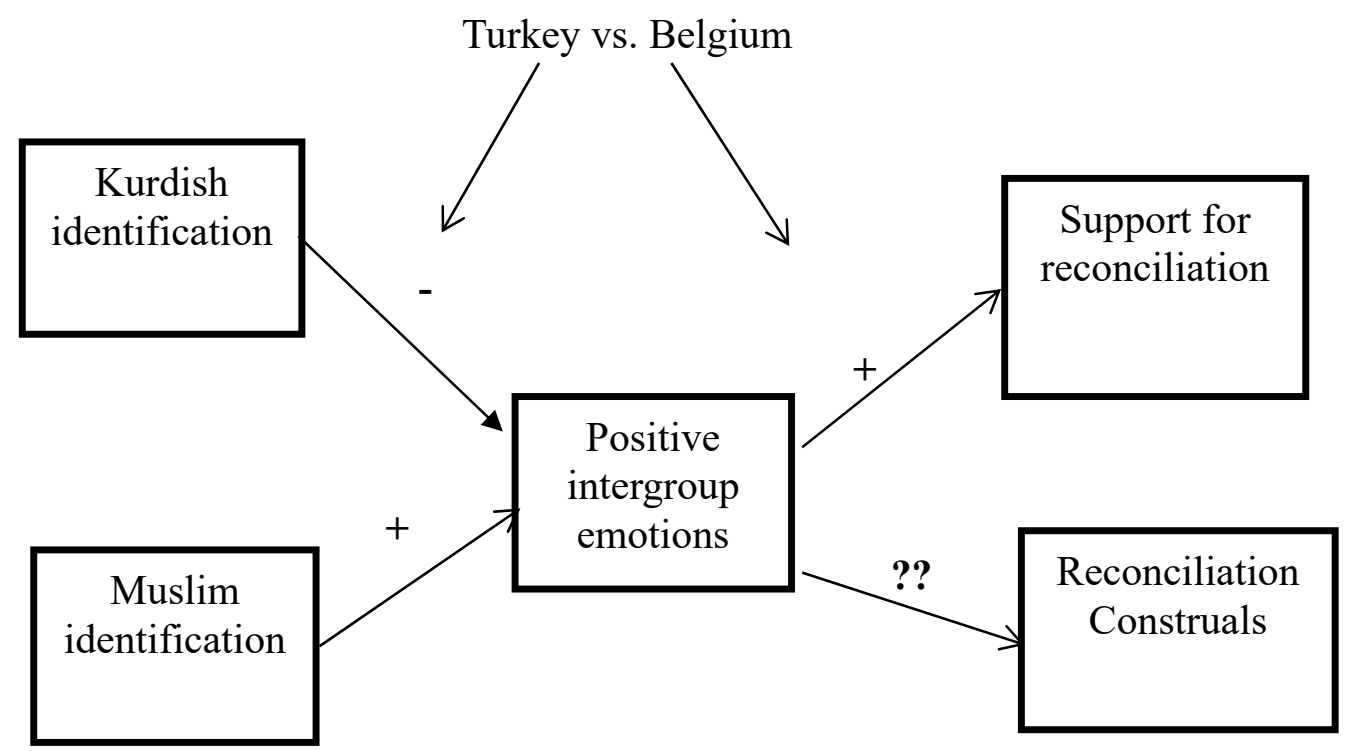

Figure 1. The theoretical mediation model where positive intergroup emotions mediate the associations of Kurdish and Muslim identifications with support for and construals of reconciliation as outcome variables 


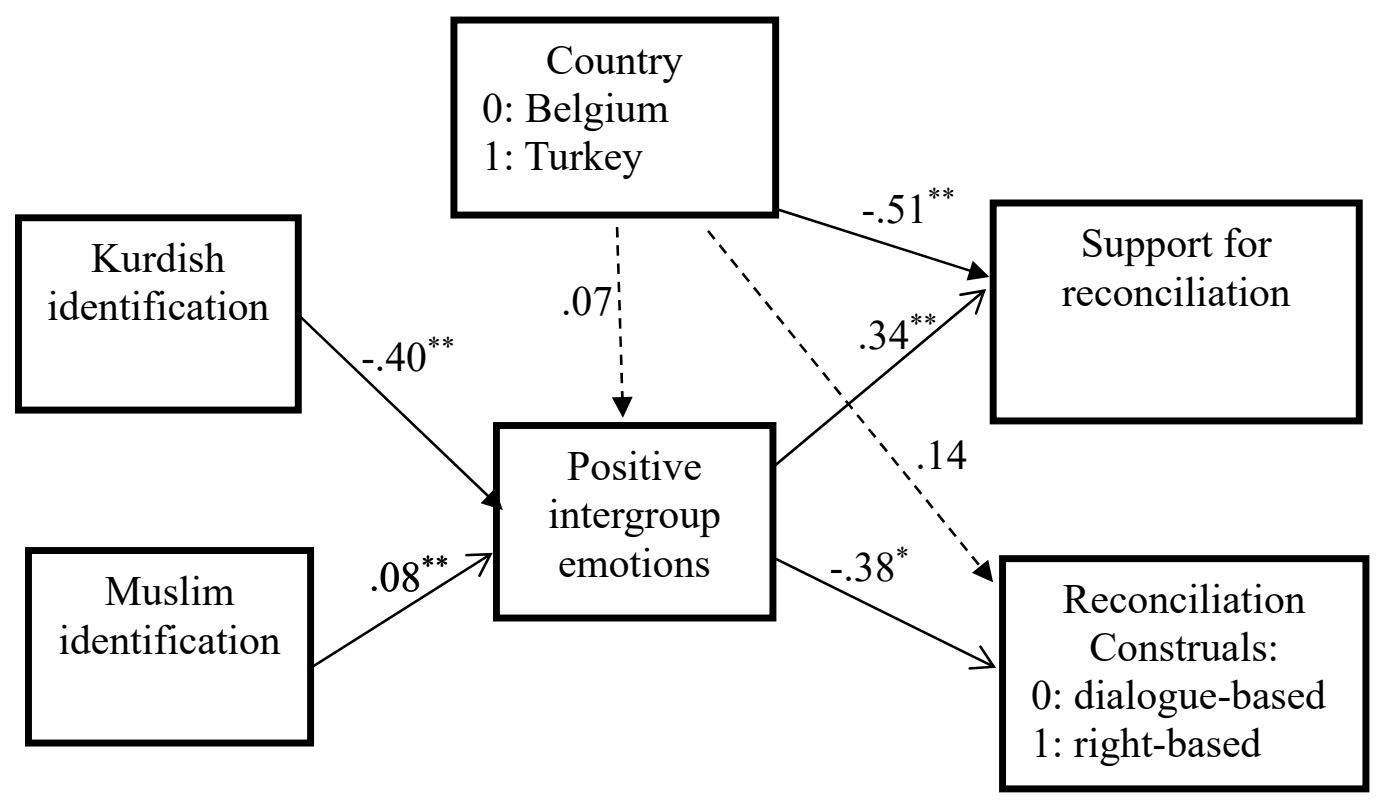

Figure 2. The final mediation model showing unstandardized bootstrapped regression coefficients.

${ }^{* * *} p<.001 ;{ }^{* *} p<.01 ;{ }^{*} p<.05$. Dashed lines indicate non-significant effects $(p>.100)$ 